\title{
PENANGGULANGAN CAMPUR TANGAN URUSAN PERADILAN DI LUAR KEKUASAAN KEHAKIMAN BERBASIS PENAL REFORM (Studi di Wilayah Hukum Pengadilan Tinggi Jawa Timur)
}

\author{
Ibnu Subarkah dan Lukman Hakim \\ Fakultas Hukum Universitas Widyagama Malang \\ Email: bn_spirit@yahoo.com; lukman_cri@yahoo.co.id
}

\begin{abstract}
The purpose of this research is to know the forms of judicial affairs' intervention outside the power of justice based on article 3 of law No. 48 in 2009 about the powers of the judiciary, and countermeasures's. The results showed that these forms are practical intervention according to some judges in the High Court of East Java, that are State Court judges in Malang, and prosecutors in Malang Regency influence the decision of the judges, the course of the trial and immediately carried out detention through bribery, gratuity, and the influence of the report towards the examination. Sets of regulations for trapping based on the unfounded Criminal Code and Act outside the Criminal Code based on the crime committed. With the increasing reports that violates the principle of presumption of innocence, and the judiciary is free from any interference from any criminal sanctions, along with the sets of regulations are lack of elucidation in the rules of the organization. Therefore the future policy makers should immediately develop the rules that integrate the internal improvement of the judiciary and external judicial's aspect, with the intention of enabling the basis, so the rules can be maintained properly while paying attention to the protection of public officials security for the judiciary.
\end{abstract}

Keywords: Countermeasures, Intervention

\begin{abstract}
Abstrak
Tujuan penelitian ini adalah untuk mengetahui bentuk-bentuk campur tangan urusan peradilan di luar kekuasaan kehakiman berdasar Pasal 3 Undang-undang No. 48 Tahun 2009 tentang kekuasaan kehakiman, dan penanggulangannya. Hasil penelitian menunjukkan bahwa bentuk-bentuk campur tangan secara praktis menurut beberapa hakim dalam wilayah Pengadilan Tinggi Jawa Timur, yaitu hakim Pengadilan Negeri Kabupaten Malang, Kota Malang, dan Jaksa Kabupaten Malang pengaruh mempengaruhi putusan hakim, jalannya persidangan dan segera dilaksanakan penahanan dilakukan melalui penyuapan, gratifikasi, dan pengaruh pemberitaan terhadap jalannya pemeriksaan. Perangkat peraturan untuk menjerat berdasar KUHP dan UU diluar KUHP yang berdasar pada Tindak Pidana yang dilakukan. Dengan semakin maraknya pemberitaan yang menyalahi asas praduga tak bersalah dan peradilan bebas lepas dari segala campur tangan dari pihak manapun perangkat sanksi pidana kurang didukung dengan penjabaran dalam peraturan pelaksananya. Oleh karena itu kedepan pengambil kebijakan harus segera menyusun peraturan yang mengintegrasikan aspek perbaikan internal peradilan dan eksternal peradilan, dengan maksud agar asas tersebut dapat terjaga dengan baik sekaligus memperhatikan perlindungan keamanan bagi pejabat publik peradilan.
\end{abstract}

Kata Kunci : Penanggulangan, Intervensi 


\section{A. Pendahuluan}

Penanggulangan penal dan non penal merupakan dasar pencegahan yang mengacu pada bahwa Indonesia adalah negara hukum menurut Pasal 1 ayat (3) UUD NRI Tahun 1945, dibutuhkan peran aktif negara untuk melindungi menurut hukum yang bercirikan pada pentingnya pemahaman pada perlindungan dan penghormatan hak asasi manusia, peradilan yang bebas, merdeka, lepas dari campur tangan pihak manapun, serta diperlukan adanya legalitas, maupun asas presumption of innocence dan equalitiy before the law.

Menilik pada pentingnya upaya memecahkan campur tangan pihak luar (intervention judiciary problem) terhadap jalannya peradilan secara legalitas barubaru ini, dalam bentuk penanggulangan Muhamad Ilham mengenukakan aspirasi tersebut nampak pada UU No. 48 Tahun 2009 tentang kekuasaan kehakiman serta peraturan yang berupaya untuk memperbaiki kinerja pengadilan yaitu PP No. 94 Tahun 2012 yang mengatur gaji pokok, tunjangan jabatan, tunjangan kemahalan, fasilitas rumah Negara, transportasi, jaminan kesehatan dan keamanan, biaya perjalanan dinas, kedudukan protokol, penghasilan pensiun dan tunjangan lain bagi hakim (Muhammad Ilham, 2013 : 4). Suatu pandangan agar tidak terjadi campur tangan ini pihak luar, disampaikan pula oleh Tamas (Indosiar Television, Siaran Wawancara, 23 April 2013, 14.45 WIB), bahwa dalam persidangan pada pejabat Jenderal DS yang terlibat kasus mesin SIMULATOR dan Pencucian Uang, pengawasan pada hakim harus maksimal, perlu posisi kontrol oleh KPK. Belum lagi laporan-laporan ditujukan pada hakim-hakim kepada Komisi Yudisial dan Mahkamah Agung tentang aspek yudisial dan perilakunya.. Hal ini berarti bahwa belumlah cukup untuk digunakan sebagai indikator yang penting masalah peningkatan kesejahteraan hakim itu dengan keluarnya Peraturan Pemerintah di atas kiranya masih terdapat indikator-indikator lainnya (Muhammad Ilham, 2013 : 14).

Tidaklah adil yang menjadi sorotan sepihak hakim saja diharapkan 2 (dua) pihak menurut kualitas tindak pidana (pada kejahatan warungan pembunuhan, dukun cabul, perkosaan anak dibawah umur, berbondong-bondongnya massa keluarga korban ke Pengadilan, dll) dan kualitas pelaku (kasus korupsi, media massa tiada hentinya memberitakan, kasus Raffi Ahmad, Kasus Aril, dll), agar asas 
persamaan dibidang hukum dan pemerintahan dan menghormati asas praduga tak bersalah dapat berjalan seimbang, maka konteks penanggulangan yang berarti penal (penerapan hukum pidana) maupun non penal (membina/menyembuhkan pelaku dan kerusakan-kerusakan dalam masyarakat) tidak cukup, dalam mencegah perilaku hakim tetapi juga mencegah perilaku pihak yang mempengaruhi hakim, maupun masyarakat lainnya, yang artinya bahwa Pasal 3 ayat (2) dan ayat (3) tidak cukup mengandung ancaman pidana sebagai unsur tindak pidana, tetapi terkandungnya norma-norma yang lebih rinci dan perlu diperbaharui.

Indryanto Seno Adji mengemukakan ide dan pemikiran serta secara factual berdasarkan fakta-fakta hukum yang ada, baik secara nasional maupun internasional, masalah tindakan yang berhubungan dengan peradilan (bc. pengadilan) telah berlangsung lama, di Negara Anglos Saxon, terutama di Negara Inggris (Indriyanto Seno Adji, 2007 : 104). Contempt of Court atau penghinaan terhadap peradilan ini merupakan istilah yang dikenal sejak abad ke 13 pada Negara-negara Anglo Saxon yang ketat dengan sistem adversary, khususnya Inggris. Pada sistem ini dikenal pula the battle of gladiator antara pengacara dan penuntut umum yang menunjukkan kebebasannya dalam persidangan, sehingga hakim yang bersikap pasif memerlukan perisai diri bagi perlindungannya. Contempt of court itu sendiri diartikan sebagai consist an act or omission substantialy disrupting or abstructing the yudicial process in a particular case, yang meliputi 2 (dua) hal yaitu contempt of facie dan contempt ex facie.

Lebih lanjut Barda Nawawi Arief menegaskan bahwa khususnya di Negara Indonesia, contempt of court di atas telah tersebar pengaturannya menurut pasalpasal dalam KUHP, misalnya Pasal 217 KUHP yang mengancam pidana bilamana “gaduh dalam persidangan”, Pasal 315 KUHP, yang mengancam pidana bilamana melakukan penghinaan dengan suatu ucapan, dll (Barda Nawawi Arief, 2011 : 3). Mengingat bahwa suatu pembaruan hukum pidana atau penal reform yang mengisyaratkan penggalian pada nilai-nilai agama dan adat, serta menanggalkan yang bersifat kolonial, Senada dengan ini Soerjono Soekanto, dikutip Abdul Wahid dan Mohibin (2009) mengemukakan hukum adalah jalinan nilai-nilai baru, yaitu dari konsepsi-konsepsi abstrakdalam diri manusia tentang apa yang dianggap baik (sehingga harus dianuti atau ditaati) dan apa yang dianggap buruk (sehingga harus 
dihindari, maka menurut hemat penulis persoalan campur tangan peradilan di luar kekuasaan kehakiman perlu diatur suatu sanksi dalam suatu peraturan perundangundangan, sebagaimana dapat diketahui dari naskah akademik Penelitian COC di bawah ini:

Tabel

Pengaturan tentang sanksi bagi pelanggar Contempt of Court

\begin{tabular}{|l|l|c|c|}
\hline No & $\begin{array}{c}\text { Diatur/dimuat dalam suatu } \\
\text { Peraturan }\end{array}$ & Jumlah & Prosentase \% \\
\hline 1 & Tidak Perlu Diatur & 58 & \\
\hline 2 & Perlu Diatur & 543 & \\
\hline 3 & Tidak Ada Jawaban & 10 & 100 \\
\hline Jumlah & 611 & \\
\hline
\end{tabular}

Sumber data : Naskah Akademik Penelitian COC, Puslitbang Hukum dan Peradilan, MARI, 2002

Berdasar paparan di atas, dapat ditarik tujuan penelitian ini, pertama, identifikasi bentuk-bentuk campur tangan urusan peradilan di luar kekuasaan kehakiman yang dilakukan oleh masyarakat; kedua, penanggulangan campur tangan urusan peradilan di luar kekuasaan kehakiman, dari kajian pada point (a) di atas, baik penal maupun non penal.

Pelaksanaan di peradilan terutama instansi pengadilan, secara normative melarang dan mencegah adanya upaya campur tangan pihak luar dalam urusan peradilan sebagaimana diatur dalam Pasal 3 dari UU No. 48 Tahun 2009 tentang Kekuasaan Kehakiman, disebutkan dalam ayat (2) dikatakan segala campur tangan dalam urusan peradilan oleh pihak lain di luar kekuasaan kehakiman dilarang, kecuali dalam hal-hal sebagaimana dimaksud dalam Undang-Undang Dasar Negara Republik Indonesia Tahun 1945, sedangkan ayat (3) dikatakan setiap orang yang dengan sengaja melanggar ketentuan sebagaimana dimaksud pada ayat (2) dipidana sesuai dengan ketentuan peraturan perundang-undangan. Dalam prakteknya campur tangan ini menimbulkan kondis pembiaran (permissiveness) yang berakibat kepercayaan kepada lembaga peradilan dikuatirkan menjadi pudar. Di bidang Pers pemberitaan suatu kasus menang atau kalah, dikabulkan atau tidak (ingat kasus Akil Mochtat) di Indonesia merupakan bentuk campur tangan, hanya saja belum dilarang. Bagir Manan (2011: 65) menegaskan tentang ulasannya terhadap hubungan Pers dengan Keterbukaan Peradilan bahwa di Indonesia, meliput, 
merekam dan menyiarkan jalan persidangan pengadilan tidak dilarang (belum dilarang).

Penanggulangan dari aspek non penal yang sudah ada dari sisi peradilan, Pemerintah mensahkan PP No. 94 Tahun 2012 mengenai perbaikan kesejahteraan hakim, sekaligus Peraturan Presden No 5 Tahun 2013 tentang hak keuangan dan Fasilitas Hakim ad hoc merupakan upaya untuk menyikapi agar hakim tidak melanggar Kode Etik dan dapat menjaga martabat, kehormatan dan keluhuran budi pekertinya yang mulai berlaku sejak 1 November 2012, yang berarti bahwa dalam konteks kebijakan kriminal, hal ini dikatakan sebagai langkah salah satu menurut hemat penulis sebagai penanggulangan internal, sebaliknya belum adanya penanggulangan eksternal pada pencari keadilan menuju pada putusan yang benar dan adil (duo prosess of law ). Oleh karena itu peluang mendiskripsikan model/kebijakan Menurut Charles O Jones (1994: 47) kebijakan adalah keputusan tetap yang dicirikan oleh konsistensi dan pengulangan (repetitiveness) tingkah laku dari mereka yang membuat dan dari mereka yang mematuhi keputusan itu.... dan kebijakan ini merupakan seperangkat ciri-ciri yang dikhususkan dan diidentifikasi melalui riset. Kebijakan ini dalam konteks lain (Willian N. Dunn: 1998: 1) dikatakan dengan analisis kebijakan yaitu aktivitas menciptakan pengetahuan tentang dan dalam proses pembuatan kebijakan, khususnya bagaimana penanggulangannya akan mendapat kepastian guna menghindari kewenanganwenangan pemerintah dan peradilan serta pencari keadilan dilakukan penelitian (research); bagi pengembangan Iptek bahwa penelitian ini bermanfaat sebagai upaya menegakkan dan mengembangkan sekaligus memperkokoh pentingnya asas 'peradilan yang bebas, lepas dari campur tanggan pihak manapun', dan tujuan hukum berupa kepastian, keadilam dan kemanfaatan guna terwujudnya independence judiciary/kemandirian peradilan.; bagi Pengembangan Institusi bahwa Penegak hukum dalam hal ini hakim-hakim pada hail temuan penelitian terdahulu, sekaligus pencari keadilan akan lebih berhati-hati dalam hal mendapatkan putusan yang berkualitas.

\section{B. Metode Penelitian}

Menurut Masri Singarimbun dan Sofyan Effendi (1989: 4-5) penelitian diskriptif merupakan penelitian untuk pengukuran yang cermat terhadap fenomena 
sosial dan budaya tertentu dengan mengembangkan konsep dan menghimpun fakta tetapi tidak melakukan pengujian hipotesa (Masri Singarimbun dan Sofyan Efendi, 1989 : 4-5). Dalam penyusunan kebijakan digunakan pola penyusunan dengan tahap-tahap yang tertentu. Menurut William N. Dun, tahap-tahap pembuatan kebijakan meliputi perumusan masalah-penyusunan agenda, peramalan-formulasi kebijakan, rekomendasi-adopsi kebijakan, pemantauan-implentasi kebijakan, penilaian-penilai kebijakan Dimana peneliti mendiskriptifkan melalui penelitian kualitatif merupakan penelitian hukum empiris di Pengadilan, diartikan sebagaimana dikemukakan oleh P. Joko Subagyo penelitian yang datanya diperoleh dari data primer maksudnya data diperoleh dengan jalan terjun ke lapangan atau data secara langsung diperoleh dari pengadilan, dengan penentuan sampel secara purposive sampling atau sampel bertujuan, secara sengaja yang memperhatikan maksud dan tujuan penelitian (Joko Subagyo, 1997 : 91).

Adapun penentuan responden dilakukan dengan cara mengambil subjek, bukan didasarkan atas strata, random, melainkan didasarkan pada tujuan tertentu. Adapun yang menjadi informan/responden adalah Hakim Pengadilan Negeri Kota Malang dan Kabupaten Malang, Jaksa pada Kejaksaan Negeri Kabupaten Malang. dimana Ronny Hanitjo Soemitro (1988: 61) mengemukakan teknik pengambilan data dilakukan dengan wawancara (interview) baik terstruktur maupun tidak terstruktur, serta pengamatan. Analisis data yang digunakan dalam penelitian ini adalah dengan cara diskriptif kualitatif yang mengikuti prosedur reduksi data, pengumpulan data, penyajian data, dan menarik kesimpulan/formulasi, dimana penganalisaan masalah yang diteliti dengan menggambarkan atau melukiskan keberadaan subjek dan objek penelitian berdasarkan fakta yang ada tanpa menggunakan angka-angka, akan tetapi mengutamakan mutu dari data yang ada.

\section{Hasil Penelitian dan Pembahasan}

Perlindungan hukum sebagai suatu gambaran dari fungsi hukum., yaitu konsep dimana hukum dapat memberikan suatu keadilan, ketertiban, kepastian, kemanfaatan dan kedamaian. Konsep penanggulangan haruslah integral dan komprehensif yang dapat diterapkan baik pada peradilan dan pada mereka yang berhubungan dengan peradilan dalam menangani perkara pidana pada khususnya. 


\section{Studi diskriptif terhadap Bentuk-bentuk Campur Tangan Urusan Peradilan di Luar Kekuasaan Kehakiman}

Ahmad Mujahidin mengatakan potret buram dunia peradilan, dilaporkan juga dalam sebuah penelitian yang ditandai dengan ketidakpuasan masyarakat terhadap kinerja lembaga peradilan dan aparatnya (Ahmad Mujahidin, 2007 : 109). AS Hakim Pengadilan Negeri Kota Malang (Wawancara dan Daftar Pertanyaan No. III, huruf b, c, d,) mengemukakan bahwa jaminan keamanan ketika memeriksa perkara adalah penting. Untuk masalah campur tangan ini tergantung pada pihak bagaimana menyikapimnya, dan harus berhati-hati ketika menyidangkan perkara. Bentuk campur tangan dapat berwujud halus (ketika hakim tersebut pernah menyidangkan kasus pembabatan tanaman oleh seorang anggota koramil) dan dalam bentuk kasar/terang-terangan. BP, Jaksa di Kejaksaan Negeri Kabupaten Malang mengemukakan bahwa adanya campur tangan dalam urusan peradilan timbul sebagai akibat timbulnya kebuntuan para pihak adanya proses peradilan yang mengedepankan asas kepastian hukum namun belum dirasakan adanya kemanfaatan maupun keadilan pihak dan kurangnya pemahaman bagi para pihak. Pentingnya pembenahan teknis administrasi peradilan sejalan dengan tuntutan perbaikan kinerja peradilan, karena pelaksanaan teknis peradilan tidak ditunjang dengan perangkat tekhnologi, administrasi peradilan dan sumber daya manusia yang memadai. Tidak memadainya perangkat teknologi seperti komputer pada suatu peradilan akan mengakibatkan lambannya penyiapan putusan pengadilan. Kondisi seperti kelangkaan perangkat kerja dan fasilitas penunjang kerja lainnya bahkan juga terjadi di Jakarta, tidak saja kota kecil di luar Pulau Jawa(ibid). Mengingat hal tersebut profesionalitas adalah sebagai faktor yang penting juga untuk ditingkatkan. Kurangnya profesionalitas akan mengakibatkan timbulnya bentuk campurtangan pihak luar. Menurut penulis bahwa hukum hanya merupakan salah satu kontol sosial saja kebiasaan, keyakinan agama, dukungan dan pencelaan kelompok-kelompok interest dan pengaruh dari pendapat umum merupakan sarana-sarana yang lebih effisien dalam mengatur tingkah laku manusia dari pada sanksi hukum. 
Oleh karena itu campur tangan dalam urusan peradilan yang bersanksi pidana tadi menurut penulis (2010: 49) lebih tegas demi kepastian sedini mungkin diklarifikasikan bentuk-bentuk pelanggaran apa yang signifikan, apakah bersifat fisik dengan anarkhisme dan penghinaan terhadap kepolisian, kejaksaan, dan kehakiman atau dalam hukum pidana Inggris sebagai pelanggaran tata tertib pengadilan (contempt of court) diluar ketentuan konstitusi Negara yakni UUD NRI Tahun 1945, yang berguna dalam hal penerapan Pasal 3 ayat (2) dan (3) Undang-undang Kekuasaan Kehakiman tersebut tidak terjebak pertama sebagai norma yang penerapannya sekehendak hati penegak hukum; yang kedua norma yang melanggar hak-hak masyarakat dalam menyampaikan pendapat, yang masih tegas mengindahkan bahwa salah tidaknya seorang yang menentukan kekuasaan kehakiman dimana sebelumnya melalui proses peradilan yang benar dan adil (duo process of law).

Makna campur tangan guna mendapatkan peradilan dan pengadilan lepas dari pengaruh pihak manapun terlebih pers, dikatakan oleh Bagir Manan bahwa menurutnya, sebagai kritik pers mengenai pengadilan dan peradilan yang berfungsi yaitu menopang pelaksanaan Undang-undang dan Peraturan Mahkamah Agung mengenai keterbukaan informasi publik; menopang pelaksanaan hak konstitusional setiap orang (publik) untuk memperoleh informasi (the rights information) sebagaimana diatur UUD 1945, Pasal 28F; memberi kesempatan kepada publik untuk menilai pelaksanaan fungsi peradilan; sebagai sumber bagi badan peradilan melakukan koreksi, melakukan tindakan atau penindakan ke dalam atas keadaan atau peristiwa yang diberitakan pers; mendorong pengadilan melaksanakan fungsi secara efisien, dan efektif terhindar dari berbagai kendala kemacetan proses peradilan; mendorong kehatihatian dalam mempertimbakgan dan memutus perkara; mendorong upaya pengadilan meningkatkan integritas, dan lingkungan peradilan yang bersih, jauh dari penyalahgunaan kekuasaan atau kesesatan (miscarriage) dalam mengadili dan memutus perkara; melindungi dan membantu pengadilan, ketika menghadapi tekanan yang tidak layak dari kekuasaan, dari publik atau kepentingan tertentu; melakukan pengawasan sosial dengan mengungkapkan kepada publik perbuatan-perbuatan yang tidak layak atau diduga tidak layak 
yang terjadi di lingkungan pengadilan atau peradilan; informasi pers merupakan sarana dialog antara publik dan pengadilan (Bagir Manan, 2011 : 68). Disamping persoalan pers dalam campur tangannya sebagaimana dikemukakan di atas, Anwar Usman (2011) mengemukakan bahwa bentuk-bentuk intervensi atau campur tangan terhadap Independensi Kekuasaan Kehakiman dilatarbelakangi oleh fenomena maraknya intervensi terhadap kebebasan hakim dan independensi kekuasaan kehakiman.

Kekuasaan merupakan sumber dari konflik. Orang yang memiliki kekuasaan akan cenderung menyalahgunakan kekuasaan itu. Dalam Black's Law Dictionary, sebagaimana dikutip oleh Indriyanto Seno Adji (2007: 198) dikemukakan any act wich is calculated to embarrass, hinder or obstruct court in administration of justice or which is calculated to lessen its authority or dignity or tending to impede or frustrate the administration of justice or by one who being under the court's authority as a party to a proceeding therein, willfull disobyes its lawfull order or fail to comply with an undertaking which he has give yang diartikan bahwa perlindungan peradilan tidak saja mencakup proses atau prosedur peradilan, tetapi juga “authority” (kekuasaan) dari institusi (peradilan) secara implicit. Dahrendorf sebagaimana dikutip oleh Alimandan, dikemukakan, perbedaan-perbedaan kepentingan dan adanya dorongan bagi yang tak memiliki kekuasaan untuk mengadakan konflik dengan yang memiliki kekuasaan, yang pertama dalam usaha memperjuangkan kekuasaan, dan yang kedua dalam usaha mempertahankannya adalah sesuatu yang tidak mungkin terhindarkan, kekuasaan adalah suatu sumber pertentangan yang abadi (Dahrenhof dalam Alimandan, 1992 : 31). Kekuasaan dan wewenang senantiasa menempatkan individu dalam posisi atas dan bawah di setiap struktur. Karena wewenang ini adalah sah, maka setiap individu yang tidak tunduk pada wewenang akan memperoleh sanksi. Oleh karena itu Dahrendorf, mengemukakan masyarakat disebut sebagai persekutuan yang terkoordinasi secara paksa (imperatively coordinated associations). Oleh French dan Raven dikutip oleh Alo Liliweri perilaku hubungan yang terlibat dalam peradilan karena kekuasaan menekan atau memaksa, yakni kemampuan orang untuk memaksa atau menekan orang lain merupakan sikap negatif, atau sama dengan 
mengurangi muatan positif lalu mengancam bawahan dengan pelbagai cara, dapat pula kekuasaan karena keahlian, yang menjelaskan bahwa orang yang mempunyai keahlian berupa pengetahuan akan mempunyai kekuasaan lebih besar dibandingkan orang yang tidak/kurang mempunyai keahlian; kekuasaan karena referensi/jaminan, yang menjelaskan, bahwa kekuasaan ini didasarkan pada derajat kepatuhan atau loyalitas bawahan terhadap atasan; kekuasaan karena legitimasi, yang mernjelaskan, bahwa kekuasaan ini didasarkan pada kepercayaan para bawahan kepada atasannya (Frech dan Raven dalam Alo Liliweri, 1997 : 138).

Chamblis, yang dikutip oleh Satjipto Rahardjo (1986) memberikan kriteria penentu yang disebut dengan faktor penentu, dalam mencermati pengadilan, yaitu 1) Tujuan yang hendaknya dicapai dengan penyelesaian sengketa itu. 2) Tingkat perlapisan yang terdapat di dalam masyarakat. Semakin tinggi tingkat perlapisan yang terdapat di dalam masyarakat, semakin besar pula perbedaan kepentingan dan nilai-nilai yang terdapat di situ. Akhirnya dari pola responsive ke perkembangan hukum menuju hukum modern dan hukum yang bersifat progresif (Mujahidin: 2006: 72) dewasa ini, diharapkan membawa karakteristik perubahan pada aspek sosiologi pengadilan. Satjipto Rahardjo mengemukakan, bahwa sejak munculnya hukum modern, maka segalanya berubah dan pengadilan menjadi struktur yang formal rasional, prosedural, dan birokratis (Satjipto Rahardjo, 1986 : 52-53). Ini adalah bagian dari perkembangan hukum yang makin menjadi institusi otonom dalam administrasi, metodologi, dan seterusnya. Nicholas Henry (1998) yang dikutip oleh Alo Liliweri (1997) Hakim sebagai bagian organisasi berikut pencari keadilannya harus terbuka. Ketertutupan organisasi mengakibatkan pembicaraan tentang pengadilan dan keadilan tiada putus-putusnya. Menurut penulis (2008: 76) bahwa dalam membahas norma Pasal 3 Ayat (2) yang akan diberi sanksi pidana dalam ayat (3) UU No. 48 Tahun 2009 tentang Kekuasaan Kehakiman sungguh penting/urgent untuk pencegahan agar mafia-mafia peradilan atau pihak-pihak yang turut dalam memengaruhi kekuasaan peradilan yang merdeka tidak akan terjadi di kemudian hari. 
Penulis mengutip Barda Nawawi Arif (2009: 35), mengemukakan bahwa dalam konteks kebijakan guna pembaharuan hukum pidana, dapat digunakan pendekatan kebijakan dan nilai (menurut pertimbangan nilai). Menurut hasil penelitian penulis di telah tersusun draft formula, terdapat 4 ayat, yang menyebutkan ayat (1) bahwa Barang Siapa Turut campur tangan dalam urusan peradilan di luar kekuasaan kehakiman akan diancam pidana. Pidana yang dimaksud menurut Tindak Pidana yang dilakukan; (2) Tindak Pidana yang dilakukan sebagaimana ditentukan dalam ayat 1 , meliputi tindak pidana fisik maupun non fisik, yang secara langsung maupun tidak langsung mempengaruhi jalannya sidang pengadilan; (3) Tindak pidana yang dimaksud dapat berupa tindakan suap, anakhisme perusakan kantor Pengadilan, atau teror-teror terhadap Hakim dan penegak hukum lainnya di tempat pengadilan.; (4)Perlindungan Hukum bagi Hakim dilakukan sejak perkara diperiksa sampai dengan putusan, baik dilakukan di Pengadilan maupun di kediaman pejabat Hakim. Formula tersebut dengan bentuk formula lainnya serta konsep penanggulangan terkandung di dalamnya upaya pembinaan dimana konsep pembinaan menurut Mangunharjana (1996: 12) adalah suatu proses belajar dengan melepaskan hal-hal yang sudah dimiliki dan mempelajari hal-hal yang belum dimiliki, dengan tujuan membantu orang yang menjalaninya untuk membetulkan dan mengembangkan pengetahuan dan kecakapan yang sudah ada serta mendapatkan pengetahuan dan kecapan baru untuk mencapai tujuan hidup dan kerja, yang sedang dialami serta secara lebih effektif.

Pembaharuan hukum pidana (penal reform) merupakan bagian dari kebijakan/politik hukum pidana (penal policy). Urgensi diadakannya pembaharuan hukum pidana dapat ditinjau dari berbagai aspek kebijakan (khususnya kebijakan sosial, kebijakan criminal, dan kebijakan penegakan hukum). Pembaharuan hukum pidana harus dilakukan dengan pendekatan kebijakan, karena memang pada hakikatnya ia hanya merupakan bagian dari suatu langkah kebijakan atau policy. Didalam setiap kebijakan terkandung pula peritimbangan nilai, oleh karena itu pembaharuan hokum pidana harus pula berorientasi pada pendekatan nilai. Pembaharuan hukum pidana (Barda Nawawi Arief : 1996) dilihat dari sudut pendekatan kebijakan adalah a. sebagai bagian 
dari kebijakan social, artinya bagian dari upaya untuk mengatasi masalahmasalah social (termasuk didalamnya masalah kemanusiaan) dalam rangka mencapai/menunjang tujuan nasional yaitu kesejahteraan masyarakat, b. sebagai bagian dari kebijakan kriminal, artinya bagian dari upaya perlindungan masyarakat (khususnya upaya penanggulangan kejahatan), c. sebagai bagian dari kebijakan penegakan hukum, artinya bagian dari upaya memperbaharui substansi hukum (legal substance) dalam rangka lebih mengefektifkan penegakan hukum. Dilihat dari sudut pendekatan nilai, pembaharuan hukum pidana merupakan upaya melakukan peninjauan dan penilaian kembali (reorientasi dan re-evaluasi) nilai-nilai sosio-politik, sosio-filosofik, dan sosiokultural yang melandasi dan memberi isi terhadap muatan normative dan substantive hokum yang dicita-citakan. Menurut Barda Nawawi Arif, (ibid) pembaharuan hukum pidana sebagaimana mengikuti pola 9 (Sembilan) pengembangan hasil Internasional Penal Reform Conference, di Royal Holloway College, University of London, pada tanggal 13-17 April 1999 yang disebutkan perlu mengembangkan restorative justice; alternative dispute resolution; informal justice; alternative to custody; alternative ways of dealing with juvenile; dealing with violent crime; reducing the prison population; the proper management of prison; the rule of civil society in penal reform.

Keterbukaan yang telah dilakukan lembaga peradilan didasarkan pada Peraturan Mahkamah Agung tentang Keterbukaan Informasi Peradilan, dimana telah dikembangkan pranata-pranata website, Internet sampai ke pengadilanpengadilan tingkat I. Menurut Bagir Manan, di Indonesia, proses peradilan, bahkan lebih terbuka daripada di negara-negara demokratik lainnya. Lebih lanjut dikemukakan bahwa di Amerika Serikat, atau Inggris, dilarang publik atau pers meliput. Merekam, apalagi menyiarkan persidangan yang sedang berjalan, atau gambar pencari keadilan di persidangan. Larangan tersebut diterapkan atas dasar. Dapat dikatakan bahwa di Indonesia, meliput, merekam dan menyiarkan jalan persidangan pengadilan tidak dilarang (belum dilarang). 


\section{Studi Diskriptif Penanggulangan Campur Tangan Urusan Peradilan di Luar Kekuasaan Kehakiman}

Masalah campur tangan urusan peradilan di luar kekuasaan kehakiman, secara ilmiah sesuai dengan pemikiran guna adanya pembaruan hukum pidana, melalui cara pengkajian kebijakan hukum pidana sebagai ilmu pidana modern, disamping kriminologi dan hukum pidana, dapat dilakukan dengan pendekatan kebijakan dan nilai. Pendekatan kebijakan dilakukan dengan mengkaji melalui pendekatan kebijakan penanggulangan baik penal maupun non penal.

Pengertian penanggulangan cukup identik dengan perlindungan hukum Perlindungan hukum adalah suatu perlindungan yang diberikan terhadap subyek hukum dalam bentuk perangkat hukum baik yang bersifat preventif maupun yang bersifat represif, baik yang tertulis maupun tidak tertulis. Dengan kata lain perlindungan hukum sebagai suatu gambaran dari fungsi hukum., yaitu konsep dimana hukum dapat memberikan suatu keadilan, ketertiban, kepastian, kemanfaatan dan kedamaian.( http://prasxo.wordpress.com/2011/02/17/definisiperlindungan-hukum) Oleh karena itu konsep penanggulangan haruslah integral dan komprehensif yang dapat diterapkan baik pada peradilan dan pada mereka yang berhubungan dengan peradilan dalam menangani perkara pidana pada khususnya. Daniel S. Nagin, Robert M. Solow, and Cynthia Lum Deterrence, mengatakan The origins of most modern theories of deterrence can be traced to the work of the Enlightenment-era legal philosophers (Beccaria, 1986 [1764]; Bentham, 1988 [1789]). Beccaria and Bentham argued that three key ingredients to the deterrence process are the severity, certainty, and celerity of punishment. These concepts, particularly the certaintyand severity of punishment, form the foundation of nearly all contemporary theories of deterrence. The enduring impact of their thinking is remarkable testimony to their innovation (Daniel S. Nagin, Robert M. Solow, and Cynthia Lum Deterrence, 2015: 74).

Sebagai usaha mewujudkan pembangunan di bidang hukum khususnya dalam menyusun suatu kebijakan kriminal, harus dilakukan secara hati-hati, integral dan komprehensif. Masalah peningkatan kesejahteraan misalnya, adalah upaya strategis guna memulihkan peningkatan kinerja dalam berbagai 
pembangunan di segala bidang. Peningkatan kesejahteraan di bidang ketenagakerjaan, di bidang informasi dan teknologi dan lain bagi pekerjanya, termasuk yang sangat rentan masalah adalah peningkatan kesejahteraan dibidang yudisial hakim yang bertujuan untuk menjaga keluhuran, martabat dan kehormatannya agar tidak mudah terpengaruh dengan campur tangan urusan peradilan oleh pihak lain di luar kekuasaan kehakiman. Suatu kondisi pembiaran-pembiaran adanya campur tangan ini akan menggelinding bagaikan bola salju akan terbentuknya Mafia Hukum. Satgas mafia hukum yang membantu Presiden harus tanggap, bahwa dalam Pembangunan di bidang hukum khususnya, hukum yang bersifat responsive, yang menanggalkan hukum represif dan otonom, secara pragmatis terimplementasikan dalam tahapan formulasi peraturan, baik pusat maupun di daerah. Philippe Nonet dan Philip Selznick mengemukakan more specifically, responsive law fosters civility in two basic ways : overcoming the parochialism of communal morality; and encouraging a problem-centered and socially integrative approach to crises of public order. (Philippe Nonet dan Philip Selznick, tanpa tahun : 91).

Sudarto mengemukakan bahwa penggunaan hukum pidana merupakan penanggulangan sesuatu gejala (Kurieren am Sympton) dan bukan suatu penyelesaian dengan menghilangkan sebab-sebabnya (Sudarto, 1983 : 35). Lebih lanjut Johannes Andenaes mengemukakan bahwa bekerjanya hukum pidana selamanya harus dilihat dari keseluruhan konteks kulturalnya (Johannes Andenaes, 1972 : 346). Ada saling pengaruh antara hukum dengan faktor-faktor lain yang membentuk sikap dan tindakan kita. Rubin dikutip Barda Nawawi Arief dalam H.D. Hart (1971: 21) menyatakan bahwa pemidanaan (apapun hakikatnya, apakah dimaksudkan untuk menghukum atau untuk memperbaiki) sedikit atau tidak mempunyai pengaruh terhadap masalah kejahatan. Sangatlah sulit untuk melakukan evaluasi terhadap efektivitas dari "general deterrence" karena mekanisme pencegahan (deterrence) itu tidak diketahui. Orang mungkin melakukan kejahatan atau mungkin mengulanginya lagi tanpa hubungan dengan ada tidaknya undang-undang atau pidana yang dijatuhkan. Sarana-sarana kontrol sosial lainnya, seperti "kekuasaan orang tua, kebiasaan-kebiasaan atau agama mungkin dapat mencegah perbuatan yang sama kuatnya dengan ketakutan orang 
pada pidana. Efektivitas hukum pidana menurut Donald R. Taft and Ralp W. England tidak dapat diukur secara akurat. Hukum hanya merupakan salah satu kontrol sosial (Donald R. Taft and Ralp W. England, 1964: 315). Kebiasaan, keyaknan agama, dukungan dan pencelaan kelompok-kelompok interest dan pengaruh dari pendapat umum merupakan sarana-sarana yang lebih effisien dalam mengatur tingkah laku manusia daripada sanksi hukum. Karl O. Christiansen mengemukakan pengaruh pidana terhadap masyarakat luas sangat sulit diukur. Pengaruh itu terdiri dari sejumlah bentuk aksi dan reaksi yang berbeda dan saling berkaitan erat, yang disebut dengan berbagai macam nama, misalnya pencegahan (deterrence), pencegahan umum (general prevention), memperkuat kembali nilai-nilai moral (reinforcement of moral values), memperkuat kesadaran kolektif (strenghening the collective solidarity), menegaskan kembali/memperkuat rasa aman dari masyarakat (reaffirmation of public feeling of security), mengurangi atau meredakan ketakutan (alleviation of fears), melepaskan ketegangan-ketegangan agresif (release of aggressive tensions) dan sebagainya (Karl O. Christiansen, 1974: 58). Dengan kata lain keterbatasan kemampuan hukum pidana antara lain dapat dilihat juga dari sifat/fungsi pemidanaan selama ini, yaitu pemidanaan individual/personal dan bukan pemidanaan yang bersifat struktural/fungsional. Herbert L. Packer (1968: 366) mengemukakan bahwa penggunaan sanksi pidana secara sembarangan/tidak pandang bulu/menyamaratakan (indiscriminately) dan digunakan secara paksa (coercively) akan menyebabkan sarana pidana itu menjadi suatu "pengancaman yang utama”. Penerapan Undang-undang Pidana, di Indonesia sebagian besar proses pidana terhadap mereka yang memilki klas rendah dari golongan ekonomi lemah. Adi Andojo Soetjipto (1995: 61) mengemukakan the actual practice of suspension of detention on bail rarely occurs in Indonesia at investigation, prosecution, or trail stages. The reason, I think is because most offenders in Indonesia are from the low-income brackets.

Makna kejahatan dalam konteks peradilan ini, terlepas pemikiran para kalangan ahli pidana dan kriminologi memandang bahwa terjadinya kejahatan karena disebabkan suatu hubungan antara pelaku dan korban. Kejahatan peradilan dalam hal ini disebabkan oleh suatu proses tentang pertentangan batin 
antara stukture dan budaya hukum (culture) masyarakat yang telah menyimpulkan (dalam tingkat kesimpulan) peradilan dalam pelaksanaan tugas keadilannya telah jauh dari kesempurnaan pencari keadilan. Satjipro Rahardjo dalam Ahmad Mujahidin (2007: 1) mengemukakan adalah suatu kenyataan untuk berburu kebenaran walaupun dalam masa tertentu harus mengakui kegagalan dan keterbatasannya karena kebenaran hasil karya manusia adalah relatif.

Arif Gosita mengemukakan kejahatan adalah hasil interaksi karena adanya interrelasi antara fenomena yang ada dan yang saling mempengaruhi. Kejahatan yang dimaksud adalah kejahatan dalam arti yang luas, yang artinya tidak hanya dirumuskan dalam Undang-undang hukum pidana saja tetapi juga tindakantindakan yang menimbulkan penderitaandan tidak dapat dibenarkan serta dianggap jahat, tidak atau belum dirumuskan dalam undang-undang dikarenakan situasi dan kondisi tertentu (Arif Gosita, 1993 : 44).

Perkembangan selanjutnya sebagaimana dikatakan Rena Yulia kejahatan terjadi tidak saja disebabkan oleh bakat tetapi juga dipengaruhi oleh lingkungan. Selanjutnya dijelaskan bahwa teori kriminologi yang mengungkap faktor-faktor terjadinya kejahatan antara lain teori differential association disamping ada unsur kelemahan dan mengalami kritik, teori ini mengetengahkan 9 proposisi, berikut dijelaskan mengungkap kejahatan dengan teori anomi yang melihat kejahatan sebagai deregulasi kebutuhan; regulasi yang keterlaluan atau fatalisme dan kurangnya intergrasi struktural atau egoism (Rena Yulia, 2010 : 89-94).

Masalah terjadinya kejahatan campur tangan urusan peradilan diluar kekuasaan kehakiman dikenal juga upaya penanggulangan non penal (bukan hukuman (pen.) ini menitikberatkan pada upaya pembinaan atau penyembuhan terpidana/pelanggar hukum (treatment of offenders) maupun dengan pembinaan/penyembuhan masyarakat (treatment of society). Menurut Habib-UrRahman Khan (1973) apabila kejahatan dipandang sebagai produk masyarakat, maka masyarakatlah yang membutuhkan perawatan/pembinaan dan bukan si penjahat, I suggest that, just as in the $19^{\text {th }}$ century attention was diverted from to its author- the criminal, we should go a step further and focus our attention, not on the criminal, but on to its author-society. We will have to change our socio- 
political and economic system that breeds criminals Pengertian treatment of society mempunyai arti upaya pembinaan/penyembuhan masyarakat dari kondisi-kondisi yang menyebabkan timbulnya kejahatan (antara lain faktor kesenjangan sosial-ekonomi, pengangguran, kebodohan, rendahnya standar hidup yang layak, kemiskinan, diskriminasi rasial dan sosial). Bertolak dari konsep "treatment of society"patut pula kiranya dikembangkan kebijakan struktural/fungsional. Dalam sistem pemidanaan yang struktural/fungsional pertanggungjawaban dan pembinaan tidak hanya tertuju secara sepihak dan fragmentair pada pelaku kejahatan, tetapi lebih ditekankan pada fungsi pemidanaan yang bersifat totalitas dan struktural, yang artinya pemidanaan tidak hanya berfungsi untuk mempertanggungjawabkan dan membina si pelaku kejahatan, tetapi berfungsi pula untuk mempertanggungjawabkan dan membina/mencegah pihak-pihak lain yang secara struktural/fungsional mempunyai potensi besar untuk terjadinya kejahatan serta berfungsi pula memulihkan atau mengganti akibat-akibat/kerugian yang timbul pada diri korban. Mengingat penjelasan di atas, kasus-kasus campur tangan urusan peradilan oleh pihak lain di luar kekuasaan kehakiman, mengakibatkan terpuruknya pembangunan di bidang hukum. Lunturnya kepercayaan pada hukum khususnya pengadilan disebabkan pelaku-pelaku hukum itu sendiri. Oleh karena itu formulasi guna pembaharuan hukum pidana dibidang hukum dan peradilan. Hal ini senada dengan Koesno Adi, dikemukakan bahwa upaya penanggulangan kejahatan secara garis besar dapat ditempuh melalui jalur “penal” yang berorientasi untuk memberantas/menumpas sesudah kejahatan terjadi ("repressive”) dan melalui jalur "non penal” yang berorientasi pada upaya untuk mencegah/menangkal sebelum kejahatan terjadi ("preventive”) (Koesno Adi, 2014 : 93).

Melihar persoalan di atas dalam Article 10 The Universal Declaration of Human Rights, dalam Thomas Flener (1999: 145) disebutkan Everyone is entitled in full equality to a fair and public hearing by an independent and impartial tribunal in the determination of his rights and obligation of any criminal charge agains him, yang mempunyai maksud bahwa setiap orang berhak dalam persamaan sepenuhnya didengarkan suaranya di muka umum dan 
secara adil oleh pengadilan yang merdeka dan tak memihak, dalam hal menetapkan hak-hak dan kewajiban-kewajibannya dan dalam setiap tuntutan pidana yang ditujukan kepadanya. Instrumen Internasional tersebut dalam pelaksanaan di peradilan terutama instansi pengadilan, secara normative melarang dan mencegah adanya upaya campur tangan pihak luar dalam urusan peradilan sebagaimana diatur dalam Pasal 3 dari UU No. 48 Tahun 2009 tentang Kekuasaan Kehakiman, disebutkan dalam ayat (1) yang berbunyi dalam menjalankan tugas dan fungsinya, hakim dan hakim konstitusi wajib menjaga kemandirian peradilan., ayat (2) dikatakan segala campur tangan dalam urusan peradilan oleh pihak lain di luar kekuasaan kehakiman dilarang, kecuali dalam hal-hal sebagaimana dimaksud dalam Undang-Undang Dasar Negara Republik Indonesia Tahun 1945, sedangkan ayat (3) yang secara langsung bersifat punishment yang berbunyi "setiap orang yang dengan sengaja melanggar ketentuan sebagaimana dimaksud pada ayat (2) dipidana sesuai dengan ketentuan peraturan perundang-undangan. Dalam prakteknya campur tangan ini menimbulkan kondisi penyakit terbentuknya mafia peradilan Apabila hal ini mengalami pembiaran (permissiveness) maka kepercayaan kepada lembaga peradilan menjadi pudar. Pemberitaan suatu kasus sebelum putusan hakimpun di Indonesia merupakan bentuk campur tangan, hanya saja belum dilarang. Bagir Manan (2011: 65) menegaskan tentang ulasannya terhadap hubungan Pers dengan Keterbukaan Peradilan bahwa di Indonesia, meliput, merekam dan menyiarkan jalan persidangan pengadilan tidak dilarang (belum dilarang) (cetak tebal. Pen.). Belum dilarangnya ini, kenyataan menunjukkan bahwa terdapat kecenderungan blow up pemberitaan yang berlebihan terhadap pejabat negara tersebut dalam hal ini hakim terutama hanya pada kasus-kasus suap dan gratifikasi. Kehendak pemerintah mensahkan PP No. 94 Tahun 2012 mengenai perbaikan kesejahteraan hakim, sekaligus Peraturan Presden No 5 Tahun 2013 tentang hak keuangan dan Fasilitas Hakim ad hoc merupakan upaya untuk menyikapi agar hakim tidak melanggar Kode Etik dan dapat menjaga martabat, kehormatan dan keluhuran budi pekertinya yang mulai berlaku sejak 1 November 2012, yang berarti bahwa dalam konteks kebijakan kriminal, tindakan pemerintah tesebut sebagai langkah menegakkan upaya 
penanggulangan dibidang non penal pada sisi internal peradilan, sebaliknya belum adanya penanggulangan eksternal pada pencari keadilan dan upaya yudisial penalnya menuju pada putusan yang benar dan adil (duo prosess of law ). Oleh karena itu peluang untuk adanya kebijakan (Charles O Jones, 1994: 47, William N Dunn: 1998: 1) dengan merumuskan tentang bentuk dan wujud campur tangan dan bagaimana penanggulangannya akan mendapat kepastian guna menghindari kesewenang-wenangan pemerintah dan peradilan serta pencari keadilan. penting untuk dilakukan upaya penelitian (research). Yang penting pula bagi pengembangan Iptek bahwa penelitian ini bermanfaat sebagai upaya menegakkan dan mengembangkan sekaligus memperkokoh pentingnya asas ‘peradilan yang bebas, lepas dari campur tanggan pihak manapun', sebagai ciri Negara Hukum (Rechtstaat) dan menegakkan asas presumption of innocence /praduga tak bersalah, dengan dampak dapat ditegakkannya konsep penanggulangan yang berbasis penal reform guna terwujudnya independence judiciary/kemandirian peradilan.; bagi Pengembangan Institusi bahwa Penegak hukum dalam hal ini hakim pada beberapa Pengadilan Negeri dalam Wilayah Hukum Pengadilan Tinggi Jawa Timur khususnya dan di Indonesia pada umumnya, menjadi terjamin dengan adanya payung hukum konkrit yang akan menjaga kuatnya birokrasi pengadilan dan aspek yudisialnya guna mendukung keluhuran kehormatan, martabat dan perilaku hakim-hakim yang dianggap sebagai "Wakil Tuhan” di dunia penuh kemuliaan dan bagi masyarakat dan instansi pemerintah serta pencari keadilan lebih berhati-hati menyikapi intervensi/campur tangan urusan peradilan di luar kekuasaan kehakiman, bahwa adanya pidana sebagai bentuk penanggulangan penal maupun non penal dapat diterapkan juga atas keterlibatannya. Harold J. Berman (1996: 267), orang-orang Amerika seperti rakyat dari tiap-tiap Negara mempunyai filsafat-filsafat hukum yang berbeda dan sering bertentangan, dengan menerima teori-teori hukum alam dan positivism. Ada yang tidak percaya akan adanya filsafat hukum dan menganggap masih mengikuti pola hukum Inggris. Koesno Adi (2014: 9-10) mengemukakan, bahwa dalam perkembangan dewasa ini terdapat kecenderungan internasional di mana masyarakat bangsa-bangsa yang beradap semakin tidak menyukai terhadap stelsel sanksi pidana yang tidak manusiawi, 
seperti sistem perumusan sanksi pidana yang sangat imperative dan pidana yang sangat berat yang menutup kemungkinan adanya perbaikan pada diri pelaku. perbaikan pada masyarakat, dan yang berdampak tentunya secara luas perbaikan pada pelaksananya atau struktur masih belum dipandang penting. Hal inilah menurut hemat penulis (2011: 150) perlu dikaji studi keadilan yang mengacu pada sistem kelembagaan peradilan menurut perspektif efektivitas peradilan satu atap/one roof system peradilan di Indonesia.

Upaya preventif dapat juga dilakukan dengan pentingnya pembenahan teknis administrasi peradilan sejalan dengan tuntutan perbaikan kinerja peradilan, karena pelaksanaan teknis peradilan tidak ditunjang dengan perangkat tekhnologi, administrasi peradilan dan sumber daya manusia yang memadai. Mengingat hal tersebut profesionalitas adalah sebagai faktor yang penting juga untuk ditingkatkan. Kurangnya profesionalitas akan mengakibatkan timbulnya bentuk campurtangan pihak luar. Oleh karena itu campur tangan dalam urusan peradilan yang bersanksi pidana tadi lebih tegas demi kepastian sedini mungkin diklarifikasikan bentuk-bentuk pelanggaran apa yang signifikan, apakah bersifat fisik dengan anarkhisme dan penghinaan terhadap kepolisian, kejaksaan, dan kehakiman atau dalam hukum pidana Inggris sebagai pelanggaran tata tertib pengadilan (contempt of court). Dalam hal penerapan Pasal 3 ayat (2) dan (3) Undang-undang Kekuasaan Kehakiman tersebut menurut penulis (2010: 49) tidak terjebak pertama sebagai norma yang penerapannya sekehendak hati penegak hukum; yang kedua norma yang melanggar hak-hak masyarakat dalam menyampaikan pendapat, yang masih tegas mengindahkan bahwa salah tidaknya seorang yang menentukan kekuasaan kehakiman dimana sebelumnya melalui proses peradilan yang benar dan adil (duo process of law). Dalam mewujudkan pembangunan di bidang hukum tentunya tidak semudah dengan membalikkan sekeping mata uang, khususnya dalam menyusun suatu kebijakan kriminal, harus dilakukan secara hati-hati, integral dan komprehensif. Masalah peningkatan kesejahteraan misalnya, adalah upaya strategis guna memulihkan peningkatan kinerja dalam berbagai pembangunan di segala bidang. Peningkatan kesejahteraan di bidang ketenagakerjaan, di bidang informasi dan teknologi dan lain bagi pekerjanya, termasuk yang sangat rentan masalah adalah peningkatan 
kesejahteraan dibidang yudisial hakim yang bertujuan untuk menjaga keluhuran, martabat dan kehormatannya agar tidak mudah terpengaruh dengan campur tangan urusan peradilan oleh pihak lain di luar kekuasaan kehakiman.

Hukum pidana sebagai sarana penanggulangan penal mempunyai banyak keterbatasan yang selama ini dijadikan sandaran hukum bagi penegak hukum (Sudarto, 1983: 35) mengemukakan bahwa penggunaan hukum pidana merupakan penanggulangan sesuatu gejala (Kurieren am Sympton) dan bukan suatu penyelesaian dengan menghilangkan sebab-sebabnya. Lebih lanjut Johannes Andenaes mengemukakan bahwa bekerjanya hukum pidana selamanya harus dilihat dari keseluruhan konteks kulturalnya (Johannes Andenaes, 1972: 346). Ada saling pengaruh antara hukum dengan faktor-faktor lain yang membentuk sikap dan tindakan kita. Rubin dalam H.D Hart (1971: 21) menyatakan bahwa pemidanaan (apapun hakikatnya, apakah dimaksudkan untuk menghukum atau untuk memperbaiki) sedikit atau tidak mempunyai pengaruh terhadap masalah kejahatan. Sangatlah sulit untuk melakukan evaluasi terhadap efektivitas dari "general deterrence" karena mekanisme pencegahan (deterrence) itu tidak diketahui (Rubin dalam H.D Hart, 1971: 21). Orang mungkin melakukan kejahatan atau mungkin mengulanginya lagi tanpa hubungan dengan ada tidaknya undang-undang atau pidana yang dijatuhkan. Sarana-sarana kontrol sosial lainnya, seperti "kekuasaan orang tua, kebiasaankebiasaan atau agama mungkin dapat mencegah perbuatan yang sama kuatnya dengan ketakutan orang pada pidana.(ibid, 15). Efektivitas hukum pidana tidak dapat diukur secara akurat. Hukum menurut Donald R. Taft and Ralp W hanya merupakan salah satu kontrol sosial. Kebiasaan, keyakinan agama, dukungan dan pencelaan kelompok-kelompok interest dan pengaruh dari pendapat umum merupakan sarana-sarana yang lebih effisien dalam mengatur tingkah laku manusia daripada sanksi hukum (Donald R. Taft and Ralp W, 1964: 315).

Karl O. Christiansen mengemukakan pengaruh pidana terhadap masyarakat luas sangat sulit diukur, dengan kata lain keterbatasan kemampuan hukum pidana antara lain dapat dilihat juga dari sifat/fungsi pemidanaan selama ini, yaitu pemidanaan individual/personal dan bukan pemidanaan yang bersifat struktural/funsional (Karl O. Christiansen, 1968: 366). Herbert L. Packer (1968) 
mengemukakan bahwa penggunaan sanksi pidana secara sembarangan/tidak pandang bulu/menyamaratakan (indiscriminately) dan digunakan secara paksa (coercively) akan menyebabkan sarana pidana itu menjadi suatu "pengancaman yang utama”.

\section{Simpulan}

1. Bentuk-bentuk pelanggaran terhadap campur tangan urusan peradilan di luar kekuasaan kehakiman, antara lain berupa penyuapan, gratifikasi dan pemberitaan peradilan yang mempengaruhi publik serta bentuk-bentuk lainnya yang masuk kategori Tindak Pidana yang bertentangan secara normatif dengan KUHP dan Undang-undang di luar KUHP. Persoalan budaya hukum, pelaksana hukum dan isi dari produk politik itu sendiri pada tiap-tiap daerah berbeda-beda. Hal berpengaruh pula pada tingkat frekuensi campur tangan serta pendekatan nilai kebenaran dan keadilan, dan sementara kajian teori bentuk campur tangan sebagai stigma penghinaan martabat peradilan berbagai macam baik secara halus maupun kasar, demi perlindungan keamanan dalam persidangan itu sendiri.

2. Penanggulangan terhadap adanya campur tangan urusan peradilan di Luar Kekuasaan Kehakiman dapat melalui penal maupun non penal. Model yang disusun berdasar pada derajat Tindak Pidana. Penanggulangan penal dengan cara menerapkan (criminal law aplication) peraturan perundang-undangan pidana yang berlaku sepanjang telah benar-benar bertentangan dengan Pasal 3 Undangundang No. 48 Tahun 2009 tentang Kekuasaan Kehakiman, khususnya sebagaimana diatur dalam ayat 3, yang berbunyi setiap orang yang dengan sengaja melanggar ketentuan sebagaimana dimaksud pada ayat (2) dipidana sesuai dengan ketentuan peraturan perundang-undangan. Penanggulangan non penal dilakukan dengan perbaikan srtuktur. kultur dan substansi, serta aspek kesejahteraan hakim yang lebih luas pada biriokrasi pengadilan secara internal, perbaikan kesrusakan-kerusakan yang ada dalam masyarakat melalui pengetahuan tentang kesadaran hukum secara eksternal. Hal ini berguna untuk pembahauan hukum pidana (penal reform) dengan secara tekstual dan kontekstual menyempurnakan peraturan yang sudah ada. 


\section{E. Saran}

1. Agar supaya hasil putusan hakim dalam hal ini melalui pintu pengadilan dan menemukan putusan yang benar dan adil, maka pelaksana hukum dalam hal ini penegak hukum dan pencari keadilan diharapakan mengerti dan memahami tentang pelaksanaan hukum itu sendiri. Pengetahuan tentang hukum dan kesadaran hukum pada para pencari keadilan ditingkatkan

2. Agar pelaksana hukum dapat menjalankan hukum sebagaimana mestinya, maka maka tidak hanya aspek penal mengalami perbaikan, aspek non penal diharapkan lebih penting juga untuk diperhatikan oleh semua pihak baik yudikatif, eksekutif dan legislatif serta masyarakat.

\section{DAFTAR PUSTAKA}

Abdul Wahid. Dkk. 2009. Etika Profesi Hukum, Rekonsrtuksi Citra Peradilan di Indonesia, Malang: Bayu Media Publishing

Achmad Mujahidin. 2007. (hasil penelitian sementara tidak dipublikasikan), Peradilan Satu Atap di Indonesia, Jakarta : PT Refika Aditama

Adi Andojo Sutjipto. 1995. Criminal Justice System of Asia, Investigation, Prosecution, and Trial, Unafei for the Prevention of Crime and the treatment offender, Tokyo: Harumicho Fuccu

Ahmad Mujahidin. 2006. "Menuju Produk Hukum Progresif (Deskripsi Pemikiran Prof. Dr. Satjipto Rahardjo, SH):. Varia Peradilan No. 247 Juni 2006. Jakarta : IKAHI

Alimandan. 1992. Sosiologi Ilmu Pengetahuan Berparadigma Ganda, dari George Ritzer, Sociology : A Multiple Paradigm Science, Jakarta : Rajawali Pers

Alo Liliweri. 1997. Sosiologi Organisasi. Bandung : PT. Citra Aditya Bhakti

Andenaes. J. 1972. Does Punishment Deter Crime ? dalam Philosopical Perspektive on Punishment. New York : Gertrude Ezorsky (Ed), New York.

Anwar. Usman. Bentuk-bentuk Intervensi Terhadap Independensi Kekuasaan Kehakiman: Relevansinya bagi Penegakan Hukum dan Keadilan di Indonesia (Penelitian Disertasi). Pascasarjana UGM : Promotion Doktor, diunduh dari Pasca.ugm.ac.id/id/promotion_view.php?dc_id=82. submitted by: admin at [31/01/2011, 09:47:46]

Arif Gosita. 1993. Masalah Korban Kejahatan. Jakarta: CV Akademika Presindo

Bagir Manan. 2011. "Pers dan Transparansi Peradilan”. Varia Peradilan, Ikatan Hakim Indonesia-Mahkamah Agung, Tahun XXVI No. 306 Mei 2011. Jakarta : IKAHI

Barda Nawawif Arif 1996. Bunga Rampai Kebijakan Hukum Pidana. Bandung : PT Citra Adtya Bakti.

2011. Pembaharuan Hukum Pidana, Dalam perspektif Kajian Perbandingan. Bandung: PT Citra Adtya Bakti

Berman, Harold J. 1996. Segi-segi Filosofis Hukum Amerika, Ceramah-ceramah tentang Hukum Amerika Serikat (Ceranah radio oleh Profesor-profesor Harvard Law Schol) terjemahan oleh Gregory Churchil, JD, PT Tatanusa 
Fleiner, Thomas. 1999. What Are Human Rights, Translated from the German by Nicholas Anson, Center for Comparative Studies University of Melbourne, Leichhart, NSW: The Federation Press,

H.F. Abraham Amos. 2007. Katastropi Hukum dan Quo Vadis Sistem Politik Peradilan Indonesia. Jakarta: PT Raja Grafindo Persada.

Hart H.D (ed), 1971.(kutipan) Punishment : For and Agains. New York City: Hart Publishing Co.Inc.

Ibnu Subarkah. 2009. “Upaya Penanggulangan Terhadap Recidive dengan pelaku Anak di Wilayah Hukum Pengadilan Negeri Kabupaten Malang (hasil penelitian). Yustisia. Jurnal Hukum. Edisi 77 Mei-Agustus 2009. Tahun XX. Terakreditasi Depdiknas RI No SK No. 43/DIKTI/Kep/ 2008, 8 juli 2008, Surakarta : UNS . 2010. "Elastisitas bagi Kemandirian Peradilan”. Varia peradilan Tahun XXV No. 295 Juni 2010. Jakarta: IKAHI-Mahkamah Agung.

2011. "Pemidanaan Campur Tangan Urusan Peradilan dalam Persepektif Organisasi dan Kekuasaan Kehakiman”. Varian Peradilan Tahun XXVII No. 302 Januari 2011. IKAHI-Mahkamah Agung, Jakarta : IKAHI.

. 2011. "Dilematiika Kekuasaan Lembaga Peradilan dan Keadilan dalam Frame Desentralisasi Pemerintahan (Suatu Common Sense)”. Jurnal Konstitusi, Puskasi Fakultas Hukum Universitas Widyagama, Malang, Volume IV No. 1 Juni 2011, ISSN 1829-7706. Jakarta: MK.

Indriyanto Seno Adji. 2007. Peradilan yang Bebas \& Contempt of Court. Jakarta : Diadit Media

Jones, Charles O. 1994. Pengantar Kebijakan Publik (Publik Policy), terjemahan oleh Ricky Istamto, Jakarta : Raja Grafindo Persada

Koesno Adi. 2014. Kebijakan Kriminal Tindak Pidana Narkotika, Konsep Penanggulangan Tindak Pidana oleh Anak. Malang: Setara Press

. 2014. Diversi Tindak Pidana Narkotika Anak. Malang: Setara Press

Kristiansen, Karl O. (kutipan) 1974. "Some Considerans on the possibility of Rational Criminal Policy”. Resource Material Series No. 7. Tokyo, UNAFEI, Tokyo.

Mangunharjana. 1996. Pembinaan, Arti dan Metodenya. Yogyakarta: Kanisius

Muhamad Ilhan. 2013. “Kesejahteraan Hakim Demi Tegaknya Keadilan”. Majalah Media Informasi Hukum dan Peradilan Komisi Yudisial. Edisi Januari-Februari. Jakarta : Komisi Yudisial.

Nagin, Daniel S et.al 2015. "Deterrence, Criminal Opportunities, and Police". Criminology Volume 53 Number 1 74-100

N. Dunn, Willian.1998. terjemahan, Pengantar Analisis Kebijakan Publik, edisi kedua, Yogyakarta : Gajah Mada University Press

Nonet, Philippe, et.al. . Law and Society in Transition, Toward Responsive Law. San Fransisco : Harper \& Row Publishers, New York, Hagerstone.

P. Joko, Subagyo,. 1997. Metode Penelitian : dalam Teori dan Praktek. Jakarta : Rineka Cipta

Packer, Herbert L. (kuitpan) 1968. The Limits of Criminal Sanction. California: Stanford University Press

Rahman Khan, Habib-Ur. 1973. "Prevention of Crime-It is society which needs "The Treatment, Not The Criminal”. Resource Material Series No. 6

Rena Yulia. 2010. Victimologi : Perlindungan Hukum Terhadap Korban Kejahatan, Edisi Pertama. Yogyakarta : Graha Ilmu 
Ronny Hanitijo Soemitro. 1988. Metode Penelitian Hukum dan Yurimetri. Jakarta : Ghalia Indonesia.

Satjipto Rahardjo. 1986. Hukum dan Masyarakat. Bandung : Angkasa.

Singarimbun,dkk. 1989. Metode Penelitian Survey. Jakarta : LP3ES.

Sudarto. 1983. Hukum pidana dan Perkembangan Masyarakat. Bandung: Sinar Baru.

Taft, Donald R. et .al. (kutipan). 1964. Criminology. New York: Mac Milan Co, New York

Zamroni.1992. Pengantar Pengembangan Teori Sosial, cetakan-I. Yogyakarta : PT. Tiara Wacana

\section{Undang-undang dan Peraturan lainnya :}

Universal Declaration of Human Right (UDHR)

UU No. 48 Tahun 2009 tentang Kekuasaan Kehakiman

Peraturan Pemerintah No. 94 Tahun 2012 tentang Perbaikan Kesejahteraan Hakim

Peraturan Presiden No. 5 Tahun 2013 tentang Hak Keuangan dan Fasilitas Hakim ad Hoc

\section{Internet /IT}

Indosiar Television, Siaran Wawancara dengan Tamas, 23 April 2013, 14.45 WIB

http://prasxo.wordpress.com/2011/02/17/definisi-perlindungan-hukum/ 